\title{
ANALISIS VALIDASI KUALITAS SOAL TES HASIL BELAJAR PADA PELAKSANAAN PROGRAM PEMBELAJARAN
}

\author{
Sudji Munadi \\ FT Universitas Negeri Yogyakarta (e-mail: sudji.munadi@uny.ac.id. \\ HP. 08164267383)
}

\begin{abstract}
An Analysis of the Validation of the Quality Achievement Tests in the Learning Program Implementation. This study aims to investigate the test types developed by FE YSU, the steps of the development and validation, and the quality based on theories. This study was a survey involving 192 lecturers who taught basic science and technology subjects in the odd semester of 2008/2009. The sample, consisting of 92 lecturers, was selected using the proportional random sampling technique. The data were collected through documents and questionnaires and analyzed using the descriptive quantitative technique. The results showed that 1) $55.42 \%$ of the lecturers developed essays tests for measuring learning achievement, $13.03 \%$ developed objective tests, and $31.55 \%$ combined both; 2 ) in the test development process, $35.87 \%$ made the test blue-prints and $23.92 \%$ did not; only $13.59 \%$ developed new tests, $2.74 \%$ used old tests, and $46.19 \%$ combined the old tests with the new ones; 3 ) $54.89 \%$ rechecked the tests and $3.73 \%$ did not, $25.50 \%$ rechecked the tests by themselves and $17.85 \%$ rechecked the tests with group members of the same subject, $2.18 \%$ had other lecturers fully check the tests, $32.85 \%$ rechecked the essay tests, $11.18 \%$ rechecked the objective tests, and $91 \%$ rechecked mostly the relevance between the test and the learning competence; and 4) theoretically, $87 \%$ of the tests developed by lecturers were good in terms of the essence of the test quality. However, there were still some weaknesses in the clarity or the function of pictures and the scoring procedure of each test item (in essay test) and the homogenity of the option length (in objective tests).
\end{abstract}

Keywords: achievement test, test quality, validation

\section{PENDAHULUAN}

Sejak bulan September 2007, Fakultas Teknik Universitas Negeri Yogyakarta (FT-UNY) melaksanakan program pendidikan dan pengajaran dengan sistem manajemen mutu ISO 9001:2000. Dengan diterapkannya sistem manajemen mutu menggunakan standar proses ini, diharapkan maha- siswa dapat memperoleh pelayanan akademik yang memuaskan dan pada akhirnya dapat menjadi lulusan yang berkualitas. Dengan diperolehnya lulusan yang berkualitas diharapkan para pengguna lulusan juga memperoleh kepuasan terhadap kinerja para lulusan. 
Salah satu indikator yang selalu menjadi tolok ukur utama untuk menilai keberhasilan pelaksanaan pendidikan dan pengajaran adalah indeks prestasi hasil belajar yang dicapai oleh mahasiswa. Indeks prestasi merupakan nilai akhir yang menggambarkan tingkat kualitas hasil belajar mahasiswa. Nilai akhir diperoleh dari proses pengolahan skor hasil belajar berdasarkan data hasil pengukuran. Untuk mendapatkan nilai akhir yang tepat sehingga mampu menunjukkan kriteria hasil belajar yang mendekati kondisi yang sesungguhnya diperlukan progam asesmen yang baik. Asesmen adalah a very general terms that describes the many techniques that we have used to measure and judge students behavior and performance (Blerkom, 2009:6). Untuk dapat melakukan asesmen kompetensi hasil belajar mahasiswa secara tepat diperlukan seperangkat instrumen tes hasil belajar yang berkualitas. Dengan instrumen yang berkualitas, dapat disajikan informasi hasil pengukuran dengan tingkat kesalahan yang sekecil mungkin sehingga keputusan yang diambil bisa tepat (Mardapi, 1999:5).

Dalam penerapan sistem manajemen mutu dituntut adanya persyaratan standar mutu pada semua aspek yang terkait dengan program pendidikan dan pengajaran sehingga mendukung proses pencapaian indeks prestasi yang tinggi. Salah satu syarat yang harus dipenuhi menurut sistem manajemen mutu ISO 9001:2000 berkaitan dengan pengukuran dan penilaian kompetensi hasil belajar mahasiswa adalah bahwa alat ukurnya harus sudah divalidasi sehingga memenuhi kaidah-kaidah sebagai alat ukur yang berkualitas. Untuk membuat soal yang berkualitas memang tidaklah mudah karena banyak faktor yang mempengaruhinya, di antaranya kemampuan dosen dan fasilitas pendukung. Menurut hemat peneliti, faktor paling dominan yang dapat mempengaruhi kualitas soal tes adalah kemampuan dosen. Dosen memegang peran penting dalam upaya melaksanakan pembelajaran yang berkualitas yang di dalamnya terdapat proses asesmen Gitomer (2007:8). Oleh karena itu, setiap dosen FT-UNY dituntut memiliki kemampuan yang memadai dalam mengembangkan dan membuat soal tes hasil belajar. Kemampuan dosen mengembangkan tes hasil belajar dapat mempengaruhi kualitas belajar mahasiswa. Dalam kaitan ini perlu diungkap lebih jauh bagaimana dosen FT-UNY melakukan validasi soal tes hasil belajar mahasiswa untuk memenuhi tuntutan persyaratan sistem manajemen mutu ISO 9001:2000. Hal ini perlu dilakukan dan penting manfaatnya dalam upaya mengantisipasi agar pelaksanaan kebijakan mutu program pembelajaran sesuai dengan yang direncanakan (Custer, 2000:128).

Salah satu kegiatan penting yang tidak bisa ditinggalkan adalah asesmen hasil belajar yang tepat yang merupakan salah satu tugas pokok seorang dosen. Kegiatan ini dimaksudkan untu mendapatkan informasi baik secara kuantitatif maupun kualitatif tentang hasil belajar mahasiswa sehingga dapat diambil keputusan- 
keputusan tertentu berkaitan dengan posisi mahasiswa selanjutnya. Harlen (2010:292) mengemukakan bahwa the summative uses of assessment can be grouped into internal and external. Internal uses include using regular grading for record keeping, informing decisions about courses to follow. Untuk itu, diperlukan kemampuan dan keterampilan dalam merencanakan dan mengembangkan soal tes hasil belajar. Menurut Sumadi (1997:28), sejumlah kemampuan yang harus dimiliki oleh dosen agar dapat membuat soal tes hasil belajar yang baik, antara lain: (1) menguasai bahan yang akan diujikan; (2) memahami tata nilai yang mendasari pendidikan; (3) memahami karakteristik peserta didik; (4) mampu menggunakan bahasa yang efektif; (5) menguasai teknik penulisan soal; dan (6) kesadaran akan kekuatan dan kelemahan dalam menulis soal.

Dua kegiatan yang saling berkaitan dalam proses evaluasi hasil belajar, yaitu pengukuran dan penilaian. Pengukuran adalah membandingkan hasil pengamatan dengan kriteria sedangkan penilaian adalah menjelaskan dan menafsirkan hasil pengukuran (Mardapi, 2008:2-6). Pengukuran diartikan sebagai pemberian angka kepada suatu atribut atau karakteristik tertentu yang dimiliki orang, hal, atau objek tertentu menurut aturan atau formulasi yang jelas (Asmawi Z. dan Noehi N., 2005). Dalam pengukuran terdapat dua karakteristik utama, yaitu penggunaan angka atau skala tertentu dan penentuan angka tersebut menurut aturan atau formula tertentu. Hasil pengukuran terhadap aktivi- tas belajar mahasiswa selalu dinyatakan dalam bentuk angka yang berskala interval. Hasil pengukuran selanjutnya dijadikan dasar untuk penilaian.

Untuk melakukan penilaian hasil belajar dapat dilakuklan dengan berbagai cara. Dalam Peraturan Menteri Pendidikan Nasional Nomor 20Tahun 2007 disebutkan bahwa teknik penilaian hasil belajar dapat berupa tes, observasi, penugasan, dan bentuk lain sesuai dengan karakteristik kompetensi dan perkembangan peserta didik. Dalam kegiatan pengukuran dan penilaian selalu ada alat yang digunakan yang biasa disebut dengan istilah tes. Test is an instrument or systematic procedure for measuring a sample of behavior (Grondlund \& Linn, 1990: 5). Reynold, Livingston, \& Wilson (2010:3). menyatakan bahwa a test is procedure in which a sample of an individual's behavior is obtained, evaluated, and scored using standardized procedures. Pendapat lain seperti yang dikemukakan oleh Nitko \& Brookhart (2007:7) bahwa $a$ test is defined as an instrument of systematic procedure for observing and describing one or more characteristics of a student using either a numerical scale or a clasification scheme. Secara ringkas dapat diartikan bahwa tes merupakan sejumlah pertanyaan yangharus dijawab, atau sejumlah pernyataan yang harus dipilih, ditanggapi, atau seperangkat tugas yang harus dilakukan oleh yang dites dengan tujuan untuk mendapatkan informasi tentang aspek-aspek tertentu dari orang yang dites tersebut (Sumarna, 
2005:19; Syaifuddin A., 2007:2; Depdikbud, 1999:15).

Tes merupakan sejumlah pertanyaan yang memiliki jawaban benar atau salah, pertanyaan yang membutuhkan jawaban, pertanyaan yang harus diberikan tanggapan dengan tujuan mengukur tingkat kemampuan seseorang atau mengungkap aspek tertentu dari orang yang dikenai tes. Dengan demikian, setiap tes menuntut keharusan adanya respons dari orang yang dites yang dapat disimpulkan sebagai suatu atribut yang dimiliki oleh orang tersebut yang sedang dicari informasinya. Secara umum, es dapat dipilah-pilahkan berdasarkan bentuk, tipe dan ragamnya. Menurut bentuknya: tes bentuk uraian/esei dan tes bentuk objektif. Tes uraian dapat dipilah menjadi tes uraian terbatas dan tes uraian bebas. Tes bentuk objektif dapat dipilah menjadi tes benar-salah, tes menjodohkan dan tes pilihan ganda. Tes pilihan ganda dapat dijabarkan lagi menjadi pilihan ganda biasa, pilihan ganda hubungan antarhal, pilihan ganda analisis kasus, pilihan ganda kompleks, dan pilihan ganda membaca diagram.

Tes hasil belajar adalah alat yang digunakan untuk mengukur kemampuan peserta didik dalam memahami kompetensi dasar satuan pembelajaran yang diikuti peserta didik tersebut. Anas Sudijono (2006:90-107) bahwa tes hasil belajar dapat dibuat dalam bentuk uraian dan bentuk objektif. Penilaian hasil belajar juga dapat dilakukan melalui berbagai cara, seperti penilaian unjuk kerja (performance), penilaian sikap, penilaian tertulis ( $p a-$ per and pencil test), penilaian proyek, penilaian produk, penilaian melalui kumpulan hasil kerja/karya peserta didik (portofolio), dan penilaian diri.

Telah dikemukakan bahwa kegiatan utama dalam pembelajaran yang tidak bisa ditinggalkan oleh dosen adalah membuat tes hasil belajar. Tes buatan dosen memiliki peran penting dalam proses pembelajaran. Kualitas tes buatan dosen dapat mempengaruhi kualitas pembelajaran dan sekaligus kualitas hasil belajar peserta didik. Dengan demikian, kemampuan dosen membuat tes dalam proses pembelajaran menjadi sesuatu yang penting dan menjadi suatu kompetensi yang harus dimiliki oleh dosen. Kusmiyati (2005:23) mengutip makna tes buatan dosen atau guru berdasarkan Goldfields District Education Office sebagai berikut.

"Teacher-made test are written or oral assessment that are not commercially produced or standardized, a test that is designed spesifically for his/her students. Teacher-made test can consist of variety of formats, including matching items, fill-inthe-bank items, true/false question, or essays."

Tes buatan dosen dimaknai sebagai suatu penilaian baik secara tertulis maupun lisan yang tidak diproduksi untuk tujuan komersial atau dibakukan, suatu tes yang dibuat khusus untuk peserta didik. Tes buatan guru atau dosen biasanya memiliki format yang beragam, baik dari tipe dan jenisnya.

Tes buatan dosen dapat dikelompokkan menjadi: (1) sesuai dengan bentuk butir yaitu uraian dan objektif; 
(2) berdasarkan tipe material stimulus yaitu verbal dan nonverbal; (3) berdasarkan tujuan; seperti achievement dan performance Berdasarkan uraian tersebut, dapat dikatakan bahwa tes buatan dosen dapat mempengaruhi efektifitas program pembelajaran dan juga hasil belajar peserta didik. Oleh karena itu, dosen dituntut untuk dapat membuat tes sendiri, baik uraian maupun objektif untuk mengukur hasil belajar mahasiswa.

Suatu tes akan memberikan arti penting jika tes tersebut memiliki butir-butir soal yang menguji tujuan yang penting dan mewakili ranah pengetahuan, kemampuan dan keterampilan secara representatif. Untuk itu, diperlukan perencanaan penyusunan tes yang baik. Menurut Asmawi Z. dan Noehi N. (2005:19), ada enam hal yang perlu diperhatikan dalam perencanaan tes, yaitu: (1) pengambilan sampel dan pemilihan butir soal; (2) tipe tes yang akan digunakan; (3) aspek yang akan diuji; (4) format butir soal; (5) jumlah butir soal; dan (6) distribusi tingkat kesukaran butir soal.

Pengembangan tes hasil belajar dapatdilakukan dengan langkah-langkah sebagai berikut: (1) pengembangan spesifikasi tes; (2) penulisan soal; (3) penelaahan soal; (4) pengujian butir-butir soal secara empiris; (5) administrasi tes bentuk akhir untuk tujuan pembakuan (Spector, 1992:8 dan Sumadi, S. 1997:2). Depdiknas (1999:23) dan Brennan (2006:17) mendeskripsikan langkah-langkah umum pengembangan tes sebagai (1) penentuan tujuan tes; (2) penyusunan kisi-kisi tes; (3) penulisan soal; (4) penelaahan so- al; (5) uji coba soal termasuk analisisnya; (6) perakitan soal menjadi perangkat tes; (7) penyajian tes; (8) skoring; (9) pelaporan hasil tes; dan (10) pemanfaatan hasil tes.

Langkah selajutnya dalam proses pengukuran dan penilaian adalah penulisan soal tes hasil belajar. Bentuk soal tes hasil belajar dapat berbentuk uraian dan objektif. Agar soal tes memiliki kualitas perlu diperhatikan kaidah-kaidah dalam penulisan soal. Menurut Depdiknas (1999), penulisan soal tes hasil belajar perlu memperhatikan kaidah-kaidah yang berkaitan dengan masalah materi, konstruksi, dan bahasa.

Langkah penting selajutnya yang harus dilakukan adalah analisis kualitas perangkat soal tes hasil belajar yang dapat dilakukan dengan dua cara, yaitu analisis secara teoritik (kualitatif) dan analisis secara empiris (kuantitatif). Analisis secara teoretis adalah telaah soal yang difokuskan pada aspek materi, konstruksi, dan bahasa. Aspek materi berkaitan dengan substansi keilmuan yang ditanyakan serta tingkat berpikir yang terlibat, aspek konstruksi berkaitan dengan teknik penulisan soal, dan aspek bahasa berkaitan dengan kekomunikatifan/kejelasan hal yang ditanyakan (Mardapi, 2004:128 dan Hayat, 1995:5-6). Langkah kegiatan seperti ini dapat diartikan sebagai analisis validasi soal. Menurut Brennan (2006:17) validation involves the development of evidence to support proposed interpretations and uses. Validation is associated with and evaluation of the extent to which the proposed interpretations and uses are 
plausible and appropriate. Menurut Thorndike (2005:145), validity refers to the degree to which evidence and theory support the interpretations of test scores entailed by proposed uses of test. Langkah validasi ini merupakan langkah penting sebelum soal dujikan. Jadi, kegiatan ini harus dilakukan oleh guru atau dosen dalam proses perencanaan dan pengembangan soal tes hasil belajar.

Analisis secara empiris adalah telaah soal tes hasil belajar berdasarkan data hasil uji coba lapangan. Untuk tes bentuk objektif, analisis difokuskan pada masalah: tingkat kesukaran, daya beda, efektifitas disktraktor, indeks kehandalan, dan kesalahan baku pengukuran (standard error measurement). Di samping itu, analisis empiris juga difokuskan pada analisis validitas dan reliabilitas.

Seperti telah dikemukakan di atas bahwa tugas utama dosen adalah melaksanakan pembelajaran. Untuk mengetahui hasil pembelajarannya, dosen yang bersangkutan harus melakukan pengukuran dengan membuat tes hasil relajar. Tes buatan dosen menjadi sangat penting artinya dalam kaitannya dengan efektivitas proses pembelajaran dan peningkatan hasil belajar mahasiswa. Berdasarkan uraian-uraian pada kajian pustaka di muka dapat dikemukakan bahwa untuk dapat membuat soal tes hasil belajar yang berkualitas perlu memperhatikan kaidah-kaidah soal yang verkualitas, baik pada proses perencanaan maupun pada proses pengembangan dan penulisannya. Tulisan ini dimaksudkan untuk mengungkap le- bih jauh bagaimana para dosen FTUNY melakukan validasi terhadap soal ujian yang mereka buat untuk mengukur hasil belajar mahasiswa yang dilaksanakan pada ujian akhir semester. Analisis validasi soal difokuskan pada analisis secara teoritis (kualitatif).

Berdasarkan uraian di atas, permasalahan yang akan diungkap lebih jauh sebagai berikut. (1) Bagaimanakah bentuk tes hasil belajar mahasiswa yang dibuat oleh dosen FT-UNY? (2) Langkah-langkah apakah yang dilakukan oleh dosen FT-UNY dalam menyusun soal tes hasil belajar mahasiswa? (3) Bagaimanakah langkahlangkah yang dilakukan oleh dosen FT-UNY dalam proses validasi soal tes hasil belajar? (4) Bagaimanakah tingkat kualitas tes hasil belajar buatan dosen FT-UNY ditinjau dari telaah teoritis (kualitatif)?

\section{METODE}

Penelitian ini telah dilaksanakan selama empat bulan, dari bulan Juni sampaidengan bulan September 2008. Penelitian dilaksanakan di FT-UNY menggunakan teknik survei terhadap objek dan subjek penelitian. Objek penelitian adalah kualitas soal tes hasil belajar semester genap 2007/2008 untuk mata kuliah bidang studi. Populasi penelitian sebagai sumber data adalah para dosen FT-UNY yang mengajar pada semester genap 2007/ 2008 untuk mata kuliah bidang studi sebanyak 92 orang. Sampel penelitian ditentukan dengan menggunakan teknik random secara proporsional 
(proportional random sampling technique).

Pengumpulan data menggunakan teknik dokumentasi dan kuesioner. Dokumentasi digunakan untuk mengumpulkan naskah-naskah soal yang terdokumen di bagian pengajaran jurusan. Kuesioner digunakan untuk menjaring data tentang langkah-langkah dalam pembuatan soal tes hasil belajar dan langkah-langkah dalam proses validasi soal yang akan diujikan. Instrumen untuk dokumentasi menggunakan lembar observasi yang berbentuk format-format untuk mencatat jumlah dan nama dosen, jumlah dan nama mata kuliah, dan bentuk tes. Instrumen kuesioner menggunakan format kuesioner terbuka dan tertutup yang dimaksudkan untuk mengungkap langkah-langkah yang dilakukan dosen, baik pada proses perencanaan, pengembangan, dan penulisan soal maupun pada proses validasi soal.

Data yang terkumpul dianalisis secara deskriptif kuantitatif. Analisis difokuskan pada pendeskripsian dalam bentuk presentase tentang langkah-langkah yang dilakukan oleh dosen pada proses perencanaan dan pengembangan soal serta hasil telaah soal secara teoretis (kualitatif).

\section{HASIL DAN PEMBAHASAN}

Analisis data hasil penelitian difokuskan pada bentuk soal yang dibuat oleh dosen, langkah-langkah dalam penyusunan soal, langkah-langkah dalam memvalidasi soal, dan kualitas soal berdasarkan tinjauan teo- retis. Deskripsi terhadap hasil analisis tersebut adalah seperti berikut.

\section{BENTUK SOAL}

Secara deskriptif, pengembangan bentuk soal tes hasil belajar yang dilakukan oleh dosen adalah (1) bentuk uraian 55,42\%; (2) bentuk objektif 13,03\%; dan (3) bentuk kombinasi uraian dan objektif $31,55 \%$.

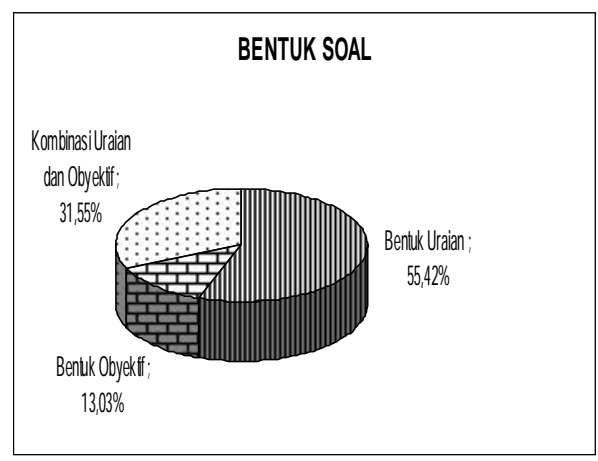

Gambar 1. Persentase Jumlah

Dosen dalam Membuat Soal

Berdasarkan hasil analisis pada Gambar 1, tampak bahwa lebih dari separoh dosen FT-UNY membuat soat tes hasil belajar dalam bentuk uraian, sedangkan sekitar $13 \%$ membuat tes bentuk objektif, dan sepertiga yang lain membuat kombinasi antara tes uraian dan tes objektif. Penyusunan soal tes hasil belajar yang cenderung berbentuk uraian dilakukan mengingat sifat mata kuliah bidang studi yang kebanyakan bidang sains dan teknologi yang bersifat aplikatif.

\section{PENYUSUNAN SOAL TES}

Dalam proses penyusunan soal terdapat dua kegiatan yang dilakukan oleh dosen, yaitu pengembangan kisikisi dan penulisan butis soal. 


\section{Pengembangan Kisi-kisi}

Persiapan yang dilakukan oleh dosen sebelum membuat soal tes hasil belajar berbeda-beda. Berikut ini fakta yang dilakukan dosen sebelum membuat soal, yaitu (1) membuat kisi-kisi soal 35,87\%; (2) tidak membuat kisikisi soal 23,92\%; dan (3) tidak jelas (tidak ada tanggapan) 40,21\%.

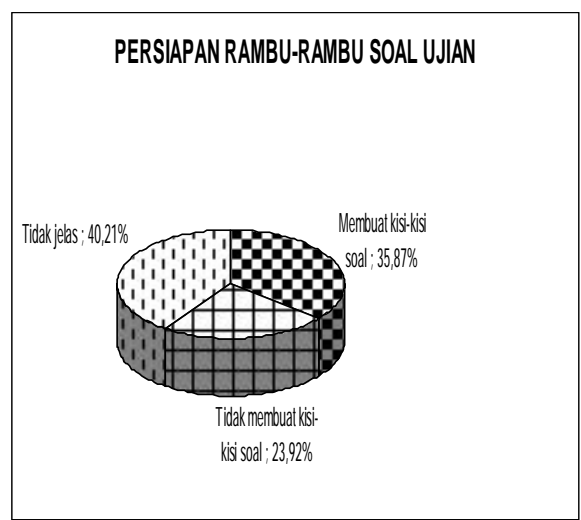

Gambar 2. Persentase Jumlah Dosen dalam Membuat Kisi-kisi Soal

Berdasarkan hasil analisis yang ditampilkan pada Gambar 2, dapat dikemukakan bahwa hanya sekitar sepertiga dosen FT-UNY yang memperhatikan kisi-kisi dalam proses penyusunan soal tes hasil belajar, sedangkan sekitar seperempatnya tidak membuat kisi-kisi. 40\% dosen tidak memberikan tanggapan apakah membuat kisi-kisi atau tidak dengan alasan bahwa pada proses pembuatan sudah memperhatikan kompetensi hasil belajar yang ditetapkan.

\section{Penulisan Soal}

Hasil analisis bagaimana dosen membuat soal untuk mengukur hasil belajar mahasiswa dapat dikelompokkan menjadi (1) membuat soal baru
13,59\%; (2) menggunakan soal tahun lalu 2,74\%; (3) kombinasi soal tahun lalu dan soal baru 46,19\%; dan (4) tidak Jelas (tidak ada tanggapan) $37,48 \%$.

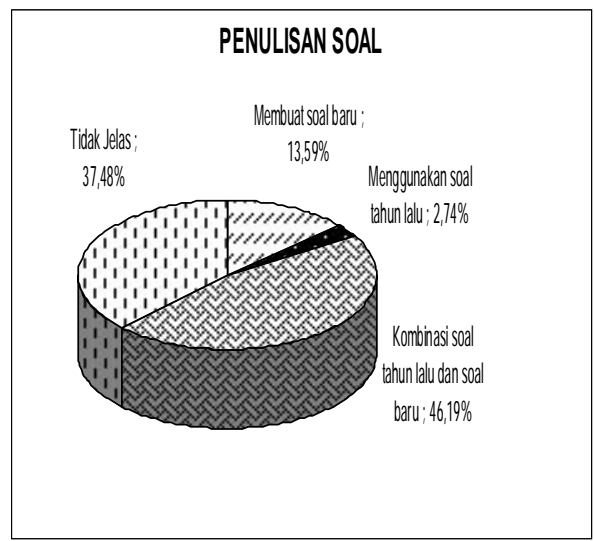

Gambar 3. Persentase Jumlah Dosen dalam Menulis Soal

Berdasarkan deskripsi data pada Tabel 3, tampak bahwa hanya sekitar 13,59\% dosen FT-UNY yang membuat soal baru untuk ujian akhir semester mahasiswa, sedangkan $46,19 \%$ dosen membuat soal kombinasi antara soal tahun lalu dan soal baru dan hanya sebagian kecil yang menggunakan soal tahun lalu. Di samping itu, terdapat sekitar sepertiga lebih dosen tidak memberikan tanggapan terhadap pembuatan soal.

\section{Validasi Teoretis}

Hasil analisis yang berkaitan dengan cara yang dilakukan dosen dalam memvalidasi kualitas soal yang sudah dibuat (1) melakukan telaah ulang 54,89\%; dan (2) tidak melakukan telaah $45,11 \%$ 


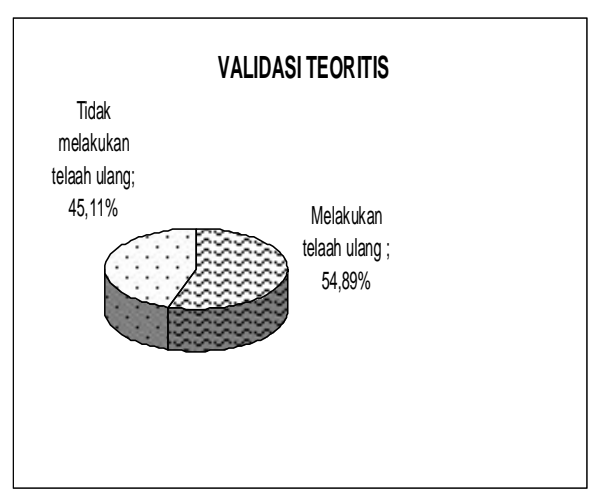

Gambar 4. Persentase Jumlah Dosen dalam Telaah Ulang

Berdasarkan Gambar 4, hanya $54,89 \%$ dosen yang melakukan tela ulang terhadap soal yang sudah disusun dalam rangka untuk menyiapkan soal tes hasil belajar yang ber- kualitas. Sisanya, 45,11\% dosen tidak melakukan telaah ulang dengan alasan bahwa telaah ini telah dilakukan pada saat pembuatan soal.

Aspek-aspek yang ditelaah ulang pada tes uraian meliputi (1) kesesuaian butir dengan kompetensi 97\%; (2) kejelasan pertanyaan dan jawaban yang diharapkan $85,50 \%$; (3) ketepatan kata tanya/perintah $71,37 \%$; (4) kejelasan petunjuk cara pengerjaan soal $70 \%$; (5) kejelasan pedoman penskoran $61 \%$; (6) kejelasan grafik/tabel/gambar/peta yang menyertai soal $49,5 \%$; dan (7) kesederhanaan penggunaan bahasa $63 \%$.

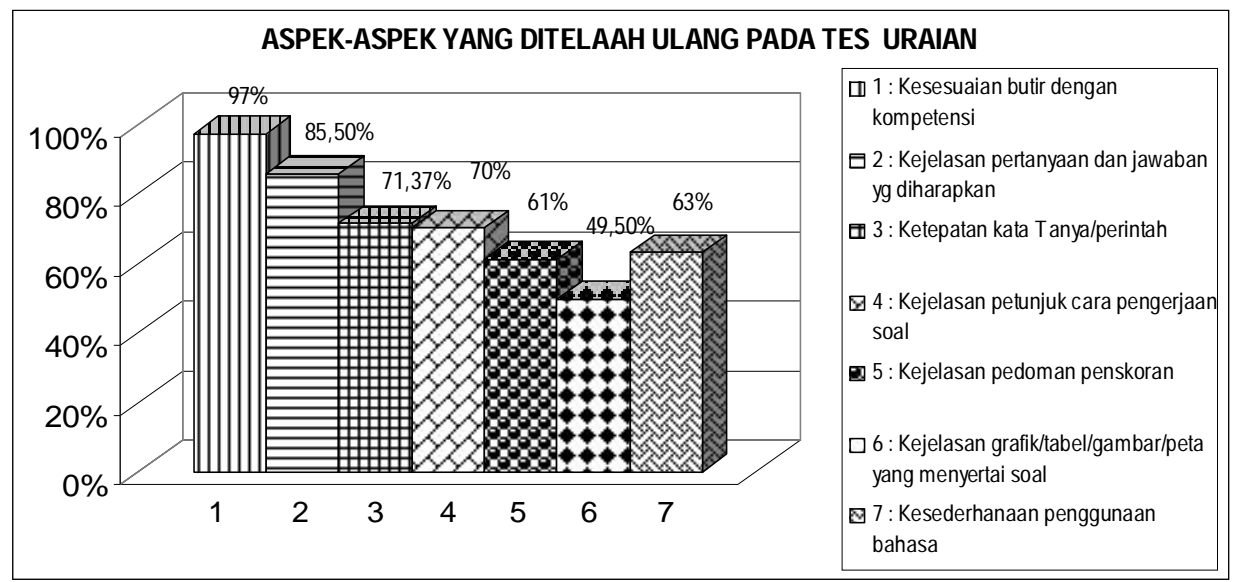

Gambar 5. Persentase Jumlah Dosen dalam Menelaah Kualitas Soal Uraian

Berdasarkan deskripsi data di atas dapat dikemukakan bahwa aspek-aspek penting berkaitan dengan kualitas tes bentuk uraian sudah ditelaah ulang oleh dosen walaupun dalam persentase jumlah yang belum optimal. Salah satu aspek penting berkaitan dengan kualitas soal, yaitu kesesuaian materi soal dengan kompeten- si hasil belajar juga telah ditelaah ulang oleh hampir semua dosen yang membuat tes uraian $(97 \%)$.

\section{Aspek yang Ditelaah Ulang pada Tes Objektif}

Aspek yang ditelaah ulang meliputi: (1) kesesuaian butir soal dengan indikator kompetensi 85,72\%; 
ketepatan alternatif jawaban yang benar 73,80\%; (3) keterkaitan pengecoh (distractor) dengan pokok soal 66,77\%; (4) kejelasan rumusan pokok soal 59,52\%; (5) kejelasan rumusan pilihan jawaban 64,28\%; (6) semua pilihan jawaban homogen $38,10 \%$; (7) ketidaktergantungan antarbutir soal satu dengan lainnya $64,28 \%$; dan (8) keberfungsian gambar/grafik $28,57 \%$.

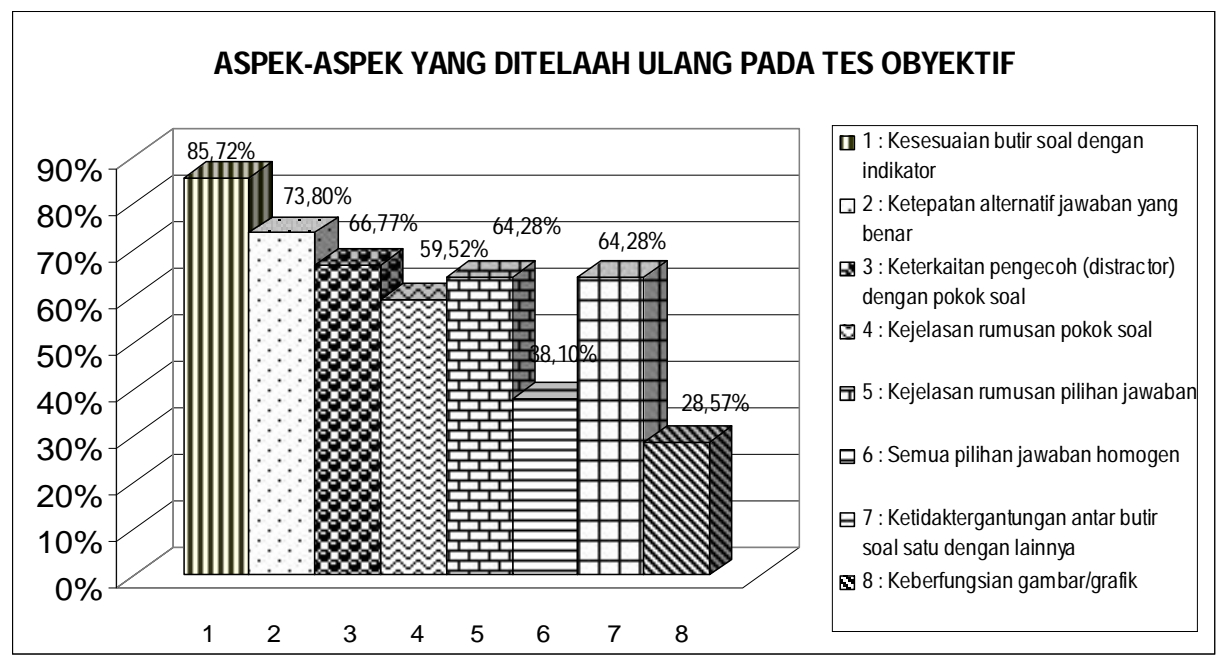

Gambar 6. Presentase Jumlah Dosen dalam Telaah Soal Objektif

Berdasarkan deskripsi data dan Gambar 6, semua aspek yang berkaitan dengan kualitas soal bentuk objektif dilakukan sudah telaah ulang secara teoretis oleh dosen, meskipun belum semua melakukannya. Namun demikian, salah satu aspek penting dalam tes objektif sudah ditelaah oleh sebagian besar dosen $(85,72 \%)$.

\section{Kualitas Soal Berdasarkan Tinjauan Teoretis}

Berdasarkan deskripsi data pada Gambar 5 dan 6 dapat dikemukakan bahwa dengan telah dilakukannya telaah ulang secara teoretis terhadap aspek-aspek yang berkaitan dengan kualitas soal maka dapat dikatakan bahwa secara keseluruhan soal tes hasil belajar yang dibuat oleh dosen $85 \%$ baik. Namun demikian, hasil analisis yang dilakukan oleh peneliti masih menemukan adanya beberapa kelemahan seperti tampak pada Tabel 1 dan 2 berikut.

Tabel 1. Persentase Jumlah Soal Bentuk Uraian yang Dinilai Lemah

\begin{tabular}{lr}
\hline No $\begin{array}{cc}\text { Aspek-aspek } \\
\text { yang Dinilai Lemah }\end{array}$ & $\begin{array}{c}\text { Jumlah } \\
\text { Soal (\%) }\end{array}$ \\
\hline 1. Tidak ada kriteria pembobotan & $36 \%$ \\
nilai pada masing-masing butir. & \\
2. Kebebasan memilih soal yang & \\
dikerjakan (jumlah soal yang & $28 \%$ \\
dibuat lebih banyak dari pada & \\
yang harus dikerjakan). & \\
\hline
\end{tabular}

Berdasarkan Tabel 1, dapat dikemukakan bahwa $36 \%$ dari semua soal bentuk uraian tidak mencantumkan bobot nilai masing-masing butir, $28 \%$ 
soal memberi kebebasan memilih soal yang dikerjakan, dan $18 \%$ perangkat soal yang dinilai lemah pada gambar yang menyertai soal.

Tabel 2. Persentase Jumlah Soal Bentuk Objektif yang Dinilai Lemah

\begin{tabular}{|c|c|c|}
\hline No & $\begin{array}{c}\text { Aspek-Aspek yang Dinilai } \\
\text { Lemah }\end{array}$ & $\begin{array}{c}\text { Jumlah } \\
\text { Soal } \\
(\%) \\
\end{array}$ \\
\hline & $\begin{array}{l}\text { Tata letak antara pokok soal dan } \\
\text { jawaban tidak satu halaman }\end{array}$ & $35 \%$ \\
\hline & $\begin{array}{l}\text { Ketidakjelasan gambar yang } \\
\text { menyertai soal }\end{array}$ & $15 \%$ \\
\hline & $\begin{array}{l}\text { Penilaian hasil belajar masih } \\
\text { cenderung dalam ranah } \\
\text { pengetahuan dan pemahaman }\end{array}$ & $34 \%$ \\
\hline
\end{tabular}

Tabel 2 di atas menunjukkan bahwa masih ditemukan dalam $35 \%$ perangkat soal yang beberapa pada butir soal pokok soalnya tidak satu halaman dengan pilihan jawaban, 15\% soal masih memiliki gambar yang menyertai soal termasuk tidak jelas. Di samping itu, terdapat $34 \%$ perangkat soal yang hanya menilai kompetensi hasil belajar terbatas pada ranah pengetahuan dan pemahaman.

Berdasarkan uraian-uraian singkat terhadap deskripsi data di atas, dapat diungkap empat hal pokok yang menjadi permasalahan dalam penelitian ini. Pertama, lebih dari separoh dosen FT-UNY $(55,42 \%)$ membuat tes hasil belajar dalam bentuk tes esei atau uraian. Hal ini dapat dimengerti karena karakteristik dari matakuliah bidang studi lebih cenderung pada aplikasi dan pemecahan masalah. Dengan bentuk tes esei, diharapkan mahasiswa dapat mengembangkan kemampuan penalaran dalam menyelesaikan berbagai problem keteknikan. Namun demikian, tidak berarti jika tes tersebut tidak bisa dibuat dalam bentuk tes obyektif. Untuk membuat tes objektif pada mata kuliah yang bersifat aplikatif membutuhkan keahlian dan kecermatan khusus sehingga soal yang tidak cenderung mengungkap kemampuan hafalan semata. Dengan demikian, tidak mengherankan jika hanya $13,03 \%$ dosen membuat soal tes hasil belajar dalam bentuk objektif yang umumnyabertipe pilihan ganda biasa. Menurut hemat penulis, sebetulnya akan lebih bermakna lagi jika tes hasil belajar dibuat dengan kombinasi antara tes esei dan tes objektif.

Kedua, dalam mengembangkan dan membuat soal, hanya $35,87 \%$ dosen membuat kisi-kisi soal, 23,92\% tidak membuat kisi-kisi soal, dan bahkan $40,21 \%$ dosen tidak jelas apakah membuat kisi-kisi soal atau tidak. Melihat data tersebut dapat juga dikatakan bahwa dalam merencanakan dan mengembangkan soal tes hasil belajar para dosen belum seluruhnya melakukan langkah-langkah awal pembuatan tes sebagaimana yang diharapkan. Hal ini tentunya belum optimal karena untuk dapat membuat soal yang baik maka kisi-kisi soal sangat diperlukan. Dengan adanya kisikisi, soal yang dibuat diharapkan tidak menyimpang dari komptensi dasar yang sudah ditetapkan. Di samping itu, sekitar $46,19 \%$ dari dosen FTUNY membuat soal dengan cara kombinasi soal baru dan soal tahun lalu. Akan lebih baik jika semua soal tes dibuat baru karena sangat dimungkinkan soal tahun lalu masih mudah 
diingat oleh mahasiswa yang kebetulan mengulang, kecuali ada modifikasi terhadap soal tahun tersebut. Berdasarkan analisis data, hanya 13,59\% dosen FT-UNY yang membuat soal yang betul-betul baru. Persentase ini memang dirasa masih rendah karena semestinya semua dosen dapat mengembangkan soal-soal tes yang baru sesuai dengan tuntutan kompetensi dan perkembangan ilmu dan teknologi.

Ketiga, dalam proses validasi dan verifikasi terhadap kualitas soal dapat dikatakan sudah cukup baik. Sebanyak $54,89 \%$ dosen FT-UNY melakukan telaah ulang terhadap soal tes hasil belajar sebelum diujikan. Namun demikian, sangat baik dan berarti jika semua dosen melakukan telaah ulang terhadap soal-soal tes yang sudah disusun. Telaah ulang mencakup tiga hal, yaitu dari aspek materi, konstruksi dan bahasa. Dikarenakan hampir $50 \%$ dosen tidak melakukan telaah ulang secara teoretis, maka dapat dimengerti jika masih ada sebagian perangkat soal tes hasil belajar yang belum memenuhi kaidah-kaidah sebagai tes yang baik. Di samping itu, telaah ulang soal yang baik jika dilakukan bersama-sama dengan dosen lain yang sebidang, tidak dilakukan sendiri. Berdasarkan analisis data, baru sebagian kecil telaah ulang dilakukan dengan dosen lain yang sebidang, yaitu sekitar $17,85 \%$. Padahal, jika telaah ulang semua dilakukan dengan dosen lain yang sebidang, ketidaktepatan bahasa dan substansi tes dapat diatasi karena adanya masukan dan saran dari berbagai pihak yang terlibat dalam telaah ulang tersebut.

Dalam menelaah soal-soal yang sudah dibuat dapat dikatakan sudah dilakukan terhadap semua aspekaspek yang seharusnya dicermati. Namun demikian, masih ada beberapa aspek yang kurang diperhatikan oleh dosen. Misalnya, untuk tes esei, mencermati kejelasan gambar hanya dilakukan oleh $49,50 \%$ dosen dan mencermati ketepatan bahasa dilakukan oleh $26,50 \%$ dosen. Hal ini dapat dikatakan bahwa dalam menelaah kedua aspek tersebut masih kurang tuntas. Padahal jika gambar yang menyertai butir soal kurang jelas akan mempengaruhi ketepatan mahasiswa dalam menjawab soal tes. Termasuk juga dari segi bahasa seharusnya tidak menimbulkan multitafsir atau beragam interpretasi. Demikian juga telaah terhadap tes objektif, ternyata tidak ada 50\% dosen FT-UNY yang melakukan telaah secara teoretis terhadap semua aspek yang semestinya diperhatikan. Terdapat tiga aspek yang masih sangat kurang diperhatikan oleh dosen dalam membuat tes bentuk objektif, yaitu homogenitas pilihan jawaban $(17,75 \%)$, panjang alternatif pilihan jawaban yang relatif sama: $(16,75 \%)$, dan telaah keberfungsian gambar/grafik (14\%). Berdasarkan data juga dapat dikatakan bahwa telaah teoretis terhadap soal tes bentuk esei lebih diperhatikan daripada telaah terhadap soal tes bentuk objektif.

Keempat, berdasarkan hasil analisis peneliti terhadap dokumen soal yang dijadikan sampel ditemukan beberapa kelemahan. Kelemahan yang 
paling dominan adalah bahwa soal tes lebih cenderung mengukur aspek pengetahuan dan pemahaman, belum banyak merambah pada aspek aplikasi, analisis, sintesis bahkan evaluasi. Padahal, untuk tingkat mahasiswa pengukuran kemampuan belajar mulai dari aplikasi sampai dengan evaluasi merupakan hal yang harus dan utama dilakukan. Di samping itu, untuk tes uraian masih ditemukan gambar-gambar yang kurang jelas, kebebasan memilih soal yang dikerjakan, dan bobot nilai untuk masing-masing butir. Hal ini semua akan mempengaruhi ketepatan kesimpulan hasil penilaian terhadap tingkat kompetensi belajar. Di samping itu, untuk tes objektif, adanya ketidakhomogenan pilihan jawaban (panjang pendeknya pernyataan semua pilihan jawaban), dan terpisahnya halaman pokok soal dengan halaman jawaban menunjukkan bahwa telaah belum dilaksanakan secara mendalam. Dengan kata lain, ada hubungan antara kegiatan yang dilakukan dalam proses telaah kualitas soal dengan berbagai kelemahan soal yang digunakan untuk ujian.

\section{KESIMPULAN}

Kecenderungan dosen FT-UNY membuat soal tes hasil belajar dalam bentuk uraian didasarkan atas karakteristik mata kuliah yang bersifat sains dan teknologi. Dengan bentuk tes uraian, lebih mudah dikembangkan soal-soal yang mampu mengungkap kemampuan aplikatif, analisis, sintesis, dan evaluasi mahasiswa dari pada tes objektif.
Dalam pengembangan soal tes hasil belajar belum semua dosen (sekitar $76 \%)$ membuat kisi-kisi soal yang dijadikan acuan penulisan butir soal. Padahal kisi-kisi sangat penting artinya pada proses penulisan soal yang baik. Di samping itu, dalam penulisan soal, sebagian besar dosen melakukan kombinasi antara soal tahun lalu dan soal baru. Pembuatan soal baru akan lebih bermakna berkaitan dengan perkembangan sains dan teknologi.

Belum semua dosen FT-UNY melakukan telaah ulang secara teoretis menyangkut kualitas soal yang sudah dibuat. Meskipun demikian, ada satu hal yang cukup baik dan positif dalam telaah ulang yang sudah dilakukan oleh sebagian besar dosen, yaitu aspek yang paling banyak ditelaah ulang adalah kesesuaian materi soal dengan kompetensi hasil belajar.

Masih ditemukan beberapa kelemahan pada sejumlah perangkat soal, yaitu pembobotan nilai tiap butir dan kebebasan memilih soal, untuk tes uraian. Untuk tes objektif, aspek yang masih lemah adalah adanya ketidakseragaman panjang pendeknya pernyataan antarpilihan jawaban, terpisahnya halaman pokok soal dengan halaman jawaban. Kelemahan lain untuk kedua bentuk tes tersebut adalah masih ada gambar-gambar yang menyertai soal yang kurang jelas.

\section{SARAN}

Berdasarkan simpulan di atas, dapat disarankan perlu adanya program atau kebijakan dalam pengembangan dan penyusunan soal tes hasil belajar mahasiswa sehingga diperoleh soa tes 
hasil belajar yang berkualitas. Lembaga perlu mengadakan program penyegaran (refreshing) bagi dosen-dosen untuk menyamakan wawasan tentang pengukuran dan penilaian hasil belajar mahasiswa.

Beberapa langkah konkret yang perlu dilakukan antara lain adalah (1) melaksanakan validasi pada semua soal yang sudah disusun sehingga soal memenuhi memenuhi kriteria substansi, konstruksi dan bahasa; (2) membuat rubrik untuk memudahkan proses penskoran pada soal-soal yang berbentuk uraian; dan (3) pengukuran hasil belajar perlu difokuskan pada aspek-aspek aplikasi, analisis, sintesis, dan evaluasi.

\section{UCAPAN TERIMA KASIH}

Artikel ini diambil dari hasil penelitian yang penulis lakukan. Penulis sangat menghargai atas dukungan berbagai pihak, khususnya yang berkaitan dengan pelaksanaan penelitian. Untuk itu, pada kesempatan ini perkenankan penulis mengucapkan banyak terima kasih kepada Dekan FTUNY beserta staf akademik yang telah membantu kelancaran pelaksanaan penelitian dan analisis data penelitian.

\section{DAFTAR PUSTAKA}

Azwar, Syaifuddin. 2000. Penyusunan Skala Psikologi. Yogyakarta: Pustaka Pelajar.

Blerkom, Van M.L. 2009. Measurement and Statistics for Teacher. New York: Routledge.
Brennan, Robert L. 2006. Educational Measurement. Fourth Editon. Road West, Westport CT: Praeger Publishers.

Custer, Rodney I., Ruhland, Sheila K., \& Stewart, Bob 2000. "Assessing Teach Prep Implementation". Journal of Vocational and Technical Education. Volume 3, Number 2, 125-135.

Depdiknas. 1999. Pengelolaan Pengujian bagi Guru Mata Pelajaran. Jakarta: Ditjen Dikdasmen, Direktorat PMU, Depdiknas.

Gitomer, Drew H. 2007. Measurement Issues and Assessment for Teaching Quality. California: Sage Publications, Inc.

Harlen, Wynne. 2010. Student Assessment and Testing. California: Sage Publications Inc.

Hayat, Bahrul, dkk. 1995. Petunjuk Pelaksanaan Pengembangan Bank Soal I Wilayah. Jakarta: Pusat Penelitian dan Pengembangan Sistem Pengujian Depdikbud.

Kusmiyati. 2005. “Karakteristik Butir Tes Ujian Akhir IPA SLTA Buatan Guru". Tesis. Tidak diterbitkan, Universitas Negeri Yogyakarta.

Mardapi, Djemari. 1999. Estimasi Kesalahan Pengukuran Alam Bidang Penidikan dan Implikasinya pada Ujian Nasional. Makalah Disajikan dalam Pidato Pengukuhan 
Guru Besar di Universitas Negeri Yogyakarta.

2008. Teknik Penyusunan Instrumen Tes dan Nontes. Yogyakarta: Mitra Cendikia Press.

Nitko, Anthony J,. \& Brookhart, Susan M. 2007. Educational Assessment of Student. New Jersey: Pearson Education Inc.

Reynolds, Cecil R., Livingstone, Ronald B., \& Wilson Victor. 2010. Measurement and Assessment in Education. New Jersey: Pearson Education Inc.

Spector, PaulE. 1992. Summated Rating Scale Construction. California: Sage Publications, Inc.
Sudijono, Anas. 2006. Pengantar Evaluasi Pendidikan. Jakarta: PT. Raja Grafindo Persada.

Suryabrata, Sumadi 1997. Pengembangan Tes Hasil Belajar. Jakarta: PT. Raja Grafindo Persada.

Thorndike, Robert L. 2005. Measurement and Evaluation in Psychology and Education. Seventh Edition. New Jersey: Pearson Education, Inc.

Zainul, Asmawi dan Nasution, Noehi 2005. Penilaian Hasil Belajar. Dirjen Dikti, Depdiknas. Jakarta. 